\title{
ANALISIS KINERJA KOPERASI SIMPAN PINJAM "TANI MAKMUR" KABUPATEN BANTUL DENGAN METODE BALANCED SCORECARD
}

\author{
Performance Analysis of Saving and Loans Cooperative "Tani Makmur" Bantul Regency \\ with Balanced Scorecard Method
}

\author{
Khottul Izzah, Suhatmini Hardyastuti, Any Suryantini
}

\begin{abstract}
Performance assessment is important to be known as a tool of data analysis, accountability and decision making. Performance assessment is done to observe both financial aspect and non-financial aspect by using Balanced Scorecard method. Balanced Scorecard become the base of Peraturan Menteri Negara Koperasi dan Usaha Kecil Menengah Republik Indonesia Nomor 14/Per/M.KUKM/XII/2009 about a tool of health assessment for Savings and Loans Cooperative. The aspects that are being analyzed are capital, productive asset quality, management, efficiency, liquidity, independence of growth, and cooperative identity. This study aims to find out the financial \& non-financial performance of KSP "Tani Makmur" Bantul Regency period 2009-2013. The kind of research is descriptive. The results showed that (1) From seven aspects assessed, aspect capital and liquidity aspect showing the worse condition than other aspect. (2) Aspect eficiency showing the best result (3) the helath level of KSP Tani Makmur in 2009-2013 is "Healthy Enough". Based on the result of this study, it's excpected that KSP "Tani Makmur" can improve their financial and non financial performance.
\end{abstract}

Keyword : Savings and Loan Cooperative, Performance, Balanced Scorecard.

\section{INTISARI}

Penilaian kinerja penting untuk diketahui sebagai alat analisis data, pertanggung jawaban dan pengambil keputusan. Analisis kinerja yang dilakukan untuk melihat aspek keuangan dan non keuangan melalui metode Balanced Scorecard. Balanced Scorecard menjadi dasar pada Peraturan Menteri Negara Koperasi dan Usaha Kecil Menengah Republik Indonesia Nomor 14/Per/M.KUKM/XII/2009 tentang pedoman Penilaian Kesehatan Koperasi Simpan Pinjam. Aspek-aspek yang dianalisis diantaranya adalah permodalan, kualitas aktiva produktif, manajemen, efisiensi, likuiditas, kemandirian dan pertumbuhan, serta jati diri koperasi. Penelitian ini bertujuan untuk mengetahui kinerja KSP Tani Makmur Kabupaten Bantul Periode 2009-2013. Penelitian bersifat deskriptif. Hasil yang diperoleh (1) Dari ketujuh aspek yang dinilai, aspek permodalan dan aspek likuiditas mempunyai nilai yang paling rendah (2) Aspek yang mempunyai nilai paling baik adalah aspek efisiensi. (3) Tingkat kesehatan KSP Tani Makmur pada tahun 2009-2013 mempunyai predikat yang sama yaitu "cukup sehat". Berdasarkan hasil penelitian yang dilakukan, diharapkan KSP Tani Makmur dapat lebih meningkatkan kinerjanya secara keseluruhan terutama pada aspek permodalan dan aspek likuiditas. Penelitian selanjutnya diharapkan dapat mengukur kinerja keuangan dan non keuangan KSP Tani Makmur dengan lebih baik lagi.

Kata kunci : Koperasi simpan pinjam, Kinerja, Balanced Scorecard.

\section{PENDAHULUAN}

Koperasi berasal dari bahasa Inggris cooperation, yang berarti usaha bersama. Secara umum, koperasi dipahami sebagai perkumpulan orang yang secara sukarela mempersatukan diri atas dasar kepentingan bersama untuk memperjuangkan peningkatan kesejahteraan ekonomi mereka dan sosialnya, melalui pembentukan sebuah perusahaan yang dikelola secara demokratis melalui suatu organisasi (Hanel, 2005).

Koperasi yang ada diharapkan dapat menempatkan diri sebagai salah satu kekuatan ekonomi Pada Daerah Kabupaten Bantul terbentuk Koperasi Simpan Pinjam dengan nama Tani Makmur yang berbadan hukum Nomor: 068/BH/VI/ 2005 pada tanggal 15 Juni 2005. KSP Tani Makmur mendapat kepercayaan untuk mengelola dana agribisnis dan dana kredit umum bagi masyarakat Kabupaten Bantul sebagai modal awal.

Penerapan Peraturan Menteri Negara Koperasi dan Usaha Kecil dan Menengah Republik Indonesia Nomor 14/Per/M.KUKM/XII/2009 yang dilakukan dengan metode Balanced Scorecard dapat memasukkan unsur keuangan dan non keuangan. 
Penerapan metode Balanced Scorecard, membantu para manajer perusahaan mengukur unit bisnis mereka dalam melakukan penciptaan nilai saat ini dengan tetap mempertimbangkan kepentingan dimasa depan.

Penelitian ini bertujuan untuk mengetahui kinerja KSP Tani Makmur dari aspek permodalan, aspek kualitas aktiva produktif, aspek manajemen, aspek efisiensi, aspek likuiditas, aspek kemandirian dan pertumbuhan, aspek jati diri koperasi serta untuk mengetahui kinerja secara keseluruhan.

\section{TINJAUAN PUSTAKA}

\section{Manajemen Keuangan Koperasi}

Manajemen keuangan koperasi merupakan keseluruhan aktivitas perusahaan yang bersangkutan dengan usaha mendapatkan dana yang diperlukan dengan biaya seminimal mungkin dan syaratsyarat yang paling menguntungkan serta usaha menggunakan dana seefisien mungkin. Aktivitas tersebut menimbulkan perbedaan yang mendasar dalam pengelolaan keuangan perusahaan koperasi dan perusahaan non koperasi. Kinerja keuangan koperasi dapat diketahui melalui analisis rasio-rasio keuangan (Hendar, 2010).

\section{Permodalan Koperasi}

Permodalan dalam koperasi didapatkan melalui tiga sumber, yaitu berasal dari anggota-anggotanya sendiri yang berupa simpanan-simpanan, dari sisa hasil usaha koperasi yang dimasukkan dalam cadangan dan dana yang berasal dari luar misalnya pinjaman (Widiyati, 2010). Hal ini sesuai dengan UU RI Pasal 66 No.17 Tahun 2012.

\section{Kualitas Aktiva Produktif}

Kualitas aktiva produktif (KAP) merupakan nilai tingkat kemungkinan dalam menerima dana yang ditanamkan pada aktiva produktif (pokok termasuk bunga) berdasarkan suatu kriteria terntetu. Aktiva merupakan manfaat ekonomi yang sangat mungkin diperoleh oleh entitas tertentu pada masa yang akan datang dalam bentuk uang ataupun jasa sebagai hasil transaksi. (Sinaga, 2000).

\section{Manajemen Koperasi}

Manajemen koperasi merupakan suatu proses yang dilakukan untuk mencapai tujuan melalui usaha bersama berdasarkan atas azas kekeluargaan. Dalam pencapaian tujuan koperasi, perlu diperhatikan adanya sistem manajemen yang baik, sehingga tujuan yang diharapkan berhasil dicapai. Menurut Hendar (2010), pandangan manajemen diterapkan dalam fungsi-fungsi manajemen yaitu perencanaan, pengorganisasian, pengarahan, pengkoordinasian dan pengendalian.

\section{Analisis Rasio Keuangan}

Pengukuran kinerja koperasi simpan pinjam dilakukan dengan menggunakan rasio-rasio yang didasarkan pada Peraturan Menteri Negara Koperasi dan Usaha Kecil dan Menengah Republik Indonesia Nomor 14/Per/M.KUKM/XII/2009 mengenai Perubahan atas Peraturan Menteri Negara Koperasi dan Usaha Kecil dan Menengah Nomor 20/Per/M.KUKM/XI/2008 tentang Pedoman Penilaian Kesehatan Koperasi Simpan dan Unit Simpan Pinjam Koperasi, yang menunjukkan bahwa kinerja koperasi menyatakan kondisinya sehat, cukup sehat, kurang sehat, tidak sehat dan sangat tidak sehat.

\section{Metode Balanced Scorecard}

Balanced Scorecard merupakan pengukuran kinerja terhadap perusahaan yang dikembangkan oleh Norton pada tahun 1996. Balanced Scorecard terdiri dari kartu skor (scorecard) dan berimbang (balanced). Kartu skor adalah kartu yang digunakan untuk mencatat skor hasil kinerja dari setiap aspek dan skor secara keseluruhan dari semua aspek. Kartu skor dapat digunakan untuk merencanakan skor yang akan diwujudkan melalui perbaikan kinerja. Kata berimbang, dimaksudkan untuk menunjukkan bahwa kinerja personil diukur secara berimbang dari dua aspek, yaitu aspek keuangan dan non keuangan, jangka pendek dan jangka panjang, intern dan ekstern. Sehingga keseimbangankeseimbangan dalam kinerja diperhatikan untuk mewujudkan skor yang baik di masa depan.

Elemen-elemen yang terdapat dalam Balanced Scorecard dapat diterjemahkan dalam perspektifperspektif mengenai tujuan dan pengukuran yang nyata, berikut uraiannya:

\section{a. Perspektif Keuangan,}

Adanya pengukuran kinerja keuangan menggambarkan apakah perencanaan, implementasi dan pelaksanaan dari strategi memberikan perbaikan yang mendasar. 


\section{b. Perspektif Pelanggan}

Perspektif pelanggan memfokuskan terhadap segmen pelanggan dan segmen pasar yang menjadi sasaran operasi pada perusahaan dan kemudian mengukur kinerja perusahaan berdasarkan target dari segmen tersebut.

\section{c. Perspektif Proses Bisnis Internal}

Perspektif proses internal mempunyai nilai-nilai yang diinginkan pelanggan sehingga perusahaan harus sebaik mungkin dalam mengidentifikasikannya.

\section{d. Perspektif Proses Belajar dan Berkembang}

Faktor-faktor yang perlu diperhatikan dalam perspektif proses belajar dan berkembang yaitu kemampuan pekerja, kemampuan sistem informasi, adanya motivasi, adanya pemberdayaan, dan perlu adanya juga pensejajaran yang dibutuhkan organisasi untuk mencapai kinerja yang diinginkan.

\section{METODE PENELITIAN}

Penelitian ini dilakukan dengan menggunakan metode dasar deskriptif analitis, yaitu suatu metode untuk meneliti status kelompok manusia, suatu kondisi dan sistem pemikiran ataupun suatu peristiwa pada masa sekarang. Tujuan penelitian deskriptif adalah membuat pencandraan secara sistematis, faktual dan akurat mengenai fakta-fakta dan sifat populasi atau daerah tertentu. Dalam studi analisis, analisis ditujukan untuk menguji hipotesis-hipotesis dan mengadakan interpretasi yang lebih dalam tentang hubungan-hubungan (Suryabrata, 2011).

\section{Metode Analisis Data}

Pada metode analisis data kuantitatif, untuk mengukur kinerja koperasi dari aspek Permodalan, aspek Kualitas Aktiva Produktif, aspek Efisiensi, aspek Likuiditas, aspek Kemandirian Dan Pertumbuhan dan aspek Jati diri Koperasi. Penilaian dilakukan dengan menggunakan sistem nilai kredit atau reward system yang dinyatakan dalam angka dengan bobot setiap aspek berbeda-beda. Reward system pada keseluruhan aspek mempunyai nilai 0 sampai dengan 100.

Berikut ini bobot peniliaian aspek dan komponen dengan menggunakan alat ukur Balanced Scorecard menurut Peraturan Menteri Negara Koperasi dan Usaha Kecil Menengah Republik Indonesia Nomor 20/Per/M.KUKM/XI/2009 tentang Pedoman
Penilaian Kesehatan Koperasi Simpan Pinjam dan Unit Simpan Pinjam Koperasi yaitu:

\section{Permodalan}

Penilaian pada aspek permodalan dinilai dengan menggunakan tiga rasio, yaitu:

a. Rasio Modal Sendiri terhadap Total Aset KSP Tani Makmur Tahun 2009-2013.

$\frac{\text { Modal sendiri }}{\text { Total Asset }} \times 100 \%$

b. Rasio Modal Sendiri terhadap Pinjaman yang Diberikan Beresiko KSP Tani Makmur Tahun 2009-2013

$\frac{\text { modal sendiri }}{\text { Pinjaman diberikan yang berisiko }} \times 100 \%$

c. Rasio Kecukupan Modal Sendiri KSP Tani Makmur Tahun 2009-2013.

$\frac{\text { modal sendiri tertimbang }}{\text { Aktiva Tertimbang Menurut Resilko }} \times 100 \%$

\section{Kualitas Aktiva Produktif}

Penilaian pada aspek kualitas aktiva produktif dinilai dengan menggunakan empat rasio, yaitu:

a. Rasio Volume Pinjaman pada Anggota terhadap Volume Pinjaman yang Diberikan KSP Tani Makmur Tahun 2009-2013.

Volume pinjaman pada anggota $\times 100 \%$ Volume pinjaman

b. Rasio Risiko Pinjaman Bermasalah terhadap Pinjaman Diberikan KSP Tani Makmur Tahun 2009-2013.

$\frac{\text { Pinjaman bermasalah }}{\text { Volume pinjaman }} \times 100 \%$

c. Rasio Cadangan Risiko terhadap Pinjaman Bermasalah KSP Tani Makmur Tahun 20092013.

$\frac{\text { Cadangan risiko }}{\text { Pinjaman bermasalah }} \times 100 \%$

d. Rasio Pinjaman yang Berisiko terhadap Pinjaman yang Diberikan KSP Tani Makmur Tahun 2009-2013.

$\frac{\text { Pinjaman yang berisiko }}{\text { Pinjaman yang diberikan }} \times 100 \%$

\section{Manajemen}

Penilaian pada aspek manajemen berdasarkan jawaban atas pertanyaan yang diajukan terhadap keseluruhan komponen KSP Tani Makmur Tahun 2009-2013, antara lain meliputi: 
a. Manajemen umum terdiri atas 12 pertanyaan sebagai berikut:

(1) Apakah KSP Tani Makmur memiliki visi, misi dan tujuan yang jelas?

(2) Apakah KSP Tani Makmur memiliki rencana kerja jangka panjang?

(3) Apakah KSP Tani Makmur memiliki rencana kerja tahunan ang digunakan sebagai dasar acuan kegiatan usaha selama 1 tahun?

(4) Adakah kesesuaian antara kerja jangka pendek dengan kerja jangka panjang?

(5) Apakah visi, misi tujuan dan rencana kerja diketahui dan dipahami pengurus, karyawan dan pengelola?

(6) Apakah pengambilan keputusan yang bersifat operasional dilakukan oleh pengelola secara independent?

(7) Apakah pengurus KSP Tani Makmur memiliki komitmen untuk menangani permsalahan yang dihadapi serta melakukan tindakan perbaikan?

(8) KSP Tani Makmur memiliki tata tertib kerja SDM?

(9) Pengurus KSP Tani Makmur yang mengangkat pengelola tidak mencampuri kegiatan operasional sehari-hari yang cenderung menguntungkan kepentingan diri sendiri, keluarga ataupun kelompoknya?

(10) AnggotaKSPsebagai pemilikimemepunyai kemampuan untuk meningkatkan permodalan?

(11) Pengurus, pengawas dan pengelola KSP didalam melakukan kegiatan operasional tidak melakukan hal-hal yang cenderung menguntungkan diri sendiri, keluarga dan kelompoknya?

(12) Apakah pengurus KSP melaksanakan fungsi pengawasan?

b. Kelembagaan terdiri atas 6 pertanyaan sebagai berikut:

(1) Apakah bagan organisasi yanga da telah mencerminkan seluruh kegiatan dan tidak merangkap jabatan kosong?

(2) Apakah KSP memiliki rincian tugas yang jelas untuk masing-masing karyawan?

(3) Apakah didalam struktur kelembagaan KSP terdapat struktur yang melakukan fungsi sebagai dewan pengawas?
(4) Apakah KSP terbukti mempunyai Standar Operasional Manajemen (SOM) dan Standar Operasional Prosedur (SOP)?

(5) Apakah KSP telah menjalankan kegiatannya sesuai SOM dan SOP koperasi?

(6) Apakah KSP mempunyai sistem pengamanan yang baik terhadap semua dokumen penting?

c. Manajemen permodalan terdiri atas 5 pertanyaan sebagai berikut:

(1) Apakah tingkat permodalan sendiri sama atau lebih besar dari tingkat pertumbuhan aset?

(2) Apakah tingkat pertumbuhan modal sendiri berasal dari anggota sekurangkurangnya sebesar $10 \%$ dibandingkan tahun sebelumnya?

(3) Apakah penyisihan cadangan dari SHU sama atau lebih besar dari seperempat SHU tahun berjalan?

(4) Apakah simpanan dan simpanan berjangka koperasi meningkat minimal $10 \%$ dari tahun sebelumnya?

(5) Apakah investasi harta tetap dari investaris serta pendanaan ekspansi perkantoran dibiayai dengan modal sendiri?

d. Manajemen aktiva terdiri atas 10 pertanyaan sebagai berikut:

(1) Apakah pinjaman dengan kolektibilitas lancar minimal $90 \%$ dari pinjaman yang diberikan?

(2) Apakah setiap pinjaman yang diberikan didukung dengan agunan yang nilainya sama atau lebih besar dari pinjaman yang diberikan kecuali pinjaman bagi anggota sampai denganm 1 juta rupiah?

(3) Apakah dana cadangan penghapusan pinjaman sama atau lebih besar dari jumlah pinjaman macet tahunan?

(4) Apakah pinjaman macet tahun lalu dapat ditagih sekurang-kurangnya sepertiganya?

(5) Apakah KSP menerapkan prosedur pinjaman dilaksanakan dengan efektif?

(6) Apakah memiliki kebijakan cadangan penghapusan bermasalah?

(7) Apakah dalam pemberian pinjaman KSP Mengambil keputusan berdasarkan prinsip kehati-hatian? 
(8) Apakah keputusan pemberian pinjaman dan atau penempatan dana dilakukan melalui komite?

(9) Apakah setelah pinjaman diberikan KSP melakukan pemantauan terhadap penggunaan pinjaman serta kemampuan dan kepatuhan anggota atau pinjaman dalam memnuhi kewajibannya?

(10) Apakah KSP melakukan peninjauan, penilaian, dan pengikat terhadap agunannya?

e. Manajemen likuiditas terdiri atas 5 pertanyaan sebagai berikut:

(1) Apakah memiliki kebijaksanaan tertulis mengenai pengendalian likuiditas?

(2) Apakah memiliki fasilitas pinjaman yang akan diterima dari lembaga lain untuk menjaga likuiditasnya?

(3) Apakah memiliki pedoman administratif yang efektif untuk memantau kewajiban yang jatuh tempo?

(4) Apakah memiliki kebijakan penghimpunan simpanan dan pemebrian pinjaman sesuai dengan kondisi keuangan $\mathrm{KSP} /$

(5) Apakah memiliki sistem infomasi yang memadai untuk pemantauan likuiditas?

\section{Efisiensi}

Penilaian pada aspek efisiensi dengan menggunakan tiga rasio, yaitu:

a. Rasio Biaya Operasi Anggota terhadap Partisipasi Bruto KSP Tani Makmur Tahun 2009-2013.

$\frac{\text { Biaya operasional anggots }}{\text { Partisipasi Bruto }} \times 100 \%$

b. Rasio Beban Usaha terhadap SHU Kotor KSP Tani Makmur Tahun 2009-2013.

$$
\frac{\text { BebanUsahe }}{\text { SHU kotor }} \times 100 \%
$$

c. Rasio Efisiensi Pelayanan KSP Tani Makmur Tahun 2009-2013.

\section{Likuiditas}

$$
\frac{\text { Biaya Karyawan }}{\text { Vohume Pinjaman }} \times 100 \%
$$

Penilaian pada aspek likuiditas dengan menggunakan dua rasio, yaitu:

a. Rasio Kas KSP Tani Makmur Tahun 2009-

\section{$\frac{\text { Kas+Bank }}{\text { Kewajiban Lancer }} \times 100 \%$}

b. Rasio Volume pinjaman yang Diberikan terhadap Dana yang Diterima KSP Tani Makmur Tahun 2009-2013.

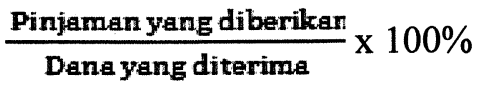

\section{Kemandirian dan Pertumbuhan}

Penilaian pada aspek kemandirian dan pertumbuhan dengan menggunakan tiga rasio, yaitu:

a. Rentabilitas aset KSP Tani Makmur Tahun 2009-2013.

$\frac{\text { SHU sebelum pajal }}{\text { Total asset }} \times 100 \%$

b. Rentabilitas Modal Sendiri KSP Tani Makmur Tahun 2009-2013.

$$
\frac{\text { SHU bagian anggota }}{\text { Total modal sendiri }} \times 100 \%
$$

c. Kemandirian Operasional Pelayanan KSP Tani Makmur Tahun 2009-2013.

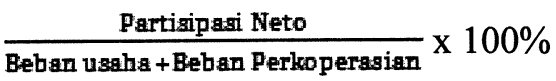

\section{Jatidiri Koperasi}

Penilaian pada aspek jatidiri koperasi dengan menggunakan dua rasio, yaitu:

a. Rasio Partisipasi Bruto KSP Tani Makmur Tahun 2009-2013.

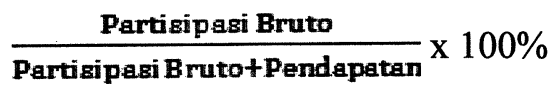

b. Rasio Promosi Ekonomi Anggota (PEA) KSP Tani Makmur Tahun 2009-2013.

$$
\frac{\text { PEA }}{\text { Simpanan pokok+gimpanan Wajit }} \times 100 \%
$$

Berdasarkan hasil perhitungan penilaian yang dilakukan terhadap aspek Permodalan, aspek Kualitas Aktiva Produktif, aspek Manajemen, aspek Efisiensi, aspek Likuiditas, aspek Kemandirian dan pertumbuhan serta aspek Jatidiri Koperasi, diperoleh skor secara keseluruhan. Skor yang didapatkan untuk menetapkan predikat tingkat kesehatan/ kinerja KSP yang dibagi dalam 5 golongan yaitu sehat, cukup sehat, kurang sehat, tidak sehat dan sangat tidak sehat. Penetapan predikat tingkat kesehatan/ kinerja KSP adalah sebagai berikut : 
Tabel 1. Penetapan Predikat Tingkat Kesehatan KSP dan USP

\begin{tabular}{cl}
\hline SKOR & PREDIKAT \\
\hline $80 \leq \mathrm{X}<100$ & SEHAT \\
$60 \leq \mathrm{X}<80$ & CUKUP SEHAT \\
$40 \leq \mathrm{X}<60$ & KURANG SEHAT \\
$20 \leq \mathrm{X}<40$ & TIDAK SEHAT \\
$<20$ & SANGAT TIDAK SEHAT \\
\hline
\end{tabular}

Sumber: Kementerian Koperasi dan UKM, 2009.

\section{HASIL DAN PEMBAHASAN}

Kinerja keuangan koperasi merupakan pengukuran keberhasilan KSP Tani Makmur pada tahun 2009-2013 dalam mencapai tujuannya yaitu dengan meningkatkan kesejahteraan anggota dan mengukur kemampuan KSP Tani Makmur dalam membayar hutang. Kinerja keuangan koperasi dapat diketahui melalui analisis rasio keuangan yang didapatkan dari Laporan Keuangan. Laporan keuangan yang tersusun baik dan memiliki kelengkapan dapat dijadikan sebagai tolak ukur keberhasilan kinerja keuangan dan sebagai alat pengendalian KSP Tani Makmur yang berguna bagi pengelola KSP, Pemerintah, Kreditor dan anggota dalam pengambilan keputusan atas kinerja keuangan. Kriteria yang digunakan dalam analisis kinerja keuangan koperasi pada penelitian ini menggunakan rasio-rasio yang ditetapkan melalui Pératuran Menteri Negara Koperasi dan Usaha Kecil dan Menengah Republik Indonesia Nomor 14/Per/M.KUKM/XII/2009 tentang Penilaian Kesehatan Koperasi Simpan Pinjam.

\section{Kinerja KSP Tani Makmur Tahun 2009-2013 dari Penilaian Beberapa Aspek}

\section{Aspek Permodalan}

Aspek permodalan merupakan aspek yang mengukur kemampuan KSP Tani Makmur dalam mengelola persediaan dana yang dimiliki yang digunakan sebagai permodalan untuk melakukan kegiatan usaha simpan-pinjam yaitu membiayai keperluan-keperluan operasional dan investasi yang terdapat didalamnya.

Berdasarkan tabel 2, KSP memiliki rasio modal sendiri terhadap total aset pada tahun 20092013 yang terletak di rasio $0 \% \leq X \leq 20 \%$. Terlihat dari standar perhitungan bahwa nilai skor 1,5 mempunyai nilai yang paling rendah dengan skala 1,5 sampai 6 sehingga dapat dikatakan bahwa
Tabel 2. Rasio Modal Sendiri terhadap Total Aset KSP Tani Makmur Tahun 2009- 2013.

\begin{tabular}{cccc}
\hline Tahun & $\begin{array}{c}\text { Modal Sendiri } \\
(\mathrm{Rp})\end{array}$ & Total Aset (Rp) & $\begin{array}{c}\text { Rasio } \\
(\%)\end{array}$ \\
2009 & 151.477 .204 & 1.644 .377 .871 & 9,21 \\
2010 & 156.048 .106 & 2.160 .424 .865 & 7,22 \\
2011 & 219.419 .611 & 2.115 .666 .157 & 10,37 \\
2012 & 200.556 .449 & 2.599 .807 .031 & 7,71 \\
2013 & 205.400 .114 & 2.776 .262 .063 & 7,40 \\
\hline
\end{tabular}

Sumber: Analisis Data Sekunder, 2014.

modal sendiri yang dimiliki masih jauh dan belum mampu mendukung pendanaan terhadap total aset yang dimilikinya.

Tabel 3. Rasio Modal Sendiri terhadap Pinjaman Diberikan Berisiko KSP Tani Makmur Tahun 2009-2013.

\begin{tabular}{cccc}
\hline Tahun & $\begin{array}{c}\text { Modal } \\
\text { Sendiri (Rp) }\end{array}$ & $\begin{array}{c}\text { Pinjaman yang } \\
\text { Diberikan Berisiko } \\
(\mathrm{Rp})\end{array}$ & $\begin{array}{c}\text { Rasio } \\
(\%)\end{array}$ \\
& & & \\
2009 & 151.477 .204 & 1.191 .317 .502 & 12,71 \\
2010 & 156.048 .106 & 1.674 .575 .943 & 9,32 \\
2011 & 219.419 .611 & 1.673 .475 .633 & 13,11 \\
2012 & 200.556 .449 & 1.784 .604 .289 & 11,24 \\
2013 & 205.400 .114 & 1.817 .161 .718 & 11,31 \\
\hline
\end{tabular}

Sumber: Analisis Data Sekunder, 2014.

Berdasarkan tebel 3 sesuai standar perhitungan rasio modal sendiri terhadap pinjaman yang diberikan beresiko, KSP Tani Makmur pada tahun 2010 memiliki nilai rasio paling rendah dan terletak pada rasio modal $0 \%<\mathrm{X} \leq 10 \%$ dan memperoleh skor terendah yaitu 0 . Pada tahun 2010 kemampuan modal sendiri yang dimiliki KSP tidak mampu untuk menanggulangi pinjaman yang diberikan berisiko. Pada tahun 2009, 2011, 2012 dan 2013 mempunyai nilai rasio yang terletak di rasio modal $10 \%<\mathrm{X} \leq 20 \%$ dan memperoleh skor 0,6 dari skala 0 sampai dengan 6,0 hal ini menggambarkan bahwa pada tahun terakhir KSP mengalami peningkatan.

Tabel 4. Rasio Kecukupan Modal Sendiri KSP Tani Makmur Tahun 2009-2013.

\begin{tabular}{cccc}
\hline Tahun & $\begin{array}{c}\text { Modal Sendiri } \\
\text { Tertimbang (Rp) }\end{array}$ & ATMR (Rp) & $\begin{array}{c}\text { Raso } \\
(\%)\end{array}$ \\
2009 & 125.625 .727 & 1.197 .291 .377 & 10,9 \\
2010 & 133.774 .687 & 1.690 .581 .278 & 7,91 \\
2011 & 168.752 .870 & 1.690 .522 .072 & 9,98 \\
2012 & 167.889 .256 & 1.804 .176 .826 & 9,31 \\
2013 & 175.243 .740 & 18.627 .062 .226 & 9,41 \\
\hline
\end{tabular}

Sumber : Analisis Data Sekunder, 2014. 
Berdasarkan tabel 4 sesuai standar perhitungan rasio kecukupan modal sendiri KSP pada tahun 2009, 2011, 2012 dan 2013 dengan rasio yang diperoleh yaitu 10,49\%, 9,98\%, 9,31\% dan $9,41 \%$ terletak pada rasio modal $>8 \%$ dengan skor 3 untuk skala 0 sampai dengan 3 artinya mempunyai nilai rasio yang tertinggi. Pada tahun 2009, 2011, 2012 dan 2013 KSP memiliki tingkat kecukupan yang tergolong tinggi. Pada tahun 2010 memiliki rasio yang lebih rendah yaitu sebesar 7,91\% dan terletak di rasio modal $6 \%<\mathrm{X} \leq 8 \%$ dengan skor 2,25 yang artinya tingkat kecukupan yang dimiliki KSP berkurang dari tahun sebelumnya.

\section{Aspek Kualitas Aktiva Produktif}

Pengertian aktiva produktif didalam KSP Tani Makmur merupakan kekayaan yang dimiliki yang digunakan untuk mendatangkan penghasilan. Dalam aspek ini terdapat aktiva produktif yang dikualifikasikan yaitu jumlah aktiva produktif yang kolektibilitasnya tidak lancar. Penanaman dana dan persiapan KSP mempunyai peran penting dalam menunjang usaha simpan pinjam. Penilaian kualitas produktif atas dasar penggolongan kolektibilitas terdiri dari lancar, kurang lancar, diragukan dan macet.

Tabel 5. Rasio Volume Pinjaman pada Anggota terhadap Pinjaman yang Diberikan KSP Tani Makmur Tahun 2009-2013.

\begin{tabular}{cccc}
\hline Tahun & $\begin{array}{c}\text { Volume Pinjaman } \\
\text { pada Anggota } \\
(\mathrm{Rp})\end{array}$ & $\begin{array}{c}\text { Volume } \\
\text { Pinjaman } \\
\text { Diberikan (Rp) }\end{array}$ & $\begin{array}{c}\text { Rasio } \\
(\%)\end{array}$ \\
2009 & $1.124 .669 .814,88$ & 1.197 .094 .002 & 93,95 \\
2010 & $1.577 .231 .492,80$ & 1.682 .918 .793 & 93,72 \\
2011 & $1.579 .593 .365,97$ & 1.685 .798 .683 & 93,69 \\
2012 & $1.679 .282 .241,36$ & 1.798 .909 .739 & 93,35 \\
2013 & $1.710 .783 .394,01$ & 1.833 .440 .568 & 93,31 \\
\hline
\end{tabular}

Sumber: Analisis Data Sekunder, 2014

Berdasarkan tabel 5, sesuai standar perhitungan rasio volume pinjaman pada anggota terhadap pinjaman yang diberikan KSP pada tahun 2009-2013 memperoleh rasio yang terletak di rasio $>75 \%$ dengan skor 10,00 untuk skala 0 sampai dengan 10. Volume pinjaman pada anggota KSP dianggap sangat baik. Selama ini KSP tergolong baik dalam memprioritaskan pinjaman kepada anggota dengan gambaran melalui rasio yang diperoleh masih diatas 50\%. Rasio yang diperoleh mengartikan bahwa prioritas pinjaman yang diberikan kepada anggota melebihi dari setengah pinjaman yang disediakan oleh KSP.

Tabel 6. Rasio Risiko Pinjaman Bermasalah terhadap Pinjaman yang Diberikan KSP Tani Makmur Tahun 2009-2013.

\begin{tabular}{cccc}
\hline Tahun & $\begin{array}{c}\text { Pinjaman } \\
\text { Bermasalah (Rp) }\end{array}$ & $\begin{array}{c}\text { Volume Pinjaman } \\
\text { Diberikan (Rp) }\end{array}$ & $\begin{array}{c}\text { Rasio } \\
(\%)\end{array}$ \\
2009 & $209.491 .450,40$ & 1.197 .094 .002 & 17,5 \\
2010 & $286.096 .194,80$ & 1.682 .918 .793 & 17 \\
2011 & $278.156 .782,70$ & 1.685 .798 .683 & 16,5 \\
2012 & $314.809 .204,40$ & 1.798 .909 .739 & 17,5 \\
2013 & $155.842 .448,30$ & 1.833 .440 .568 & 8,5 \\
\hline
\end{tabular}

Sumber: Analisis Data Sekunder, 2014.

Berdasarkan tabel 6 sesuai standar perhitungan rasio risiko pinjaman bermasalah terhadap pinjaman yang diberikan pada tahun 2009-2012 tedapat pinjaman yang bermasalah di KSP. Rasio yang diperoleh terletak di $10 \%<\mathrm{X} \leq 20 \%$ dengan skor yang diperoleh 3,0 artinya terdapat pinjaman bermasalah yang masih ada untuk ditangani KSP. Pada tahun 2013, pinjaman bermasalah semakin berkurang karena pinjaman macet dapat diatasi oleh KSP melalui kebijakan pemberian pinjaman kepada anggota yang lebih efektif. Angka rasio yang didapatkan pada tahun 2013 terletak di rasio $0 \%<\mathrm{X} \leq 10 \%$ dengan skor 4,00 untuk skala 0 sampai dengan 5 artinya ada pengurangan pinjaman bermasalah KSP dari tahun-tahun sebelumnya.

Tabel 7. Rasio Cadangan Risiko terhadap Pinjaman Bermasalah KSP Tani Makmur Tahun 20092013

\begin{tabular}{cccc}
\hline Tahun & $\begin{array}{c}\text { Cadangan } \\
\text { Risiko (Rp) }\end{array}$ & $\begin{array}{c}\text { Pinjaman } \\
\text { Bermasalah (Rp) }\end{array}$ & $\begin{array}{c}\text { Rasio } \\
(\%)\end{array}$ \\
2009 & 78.611 .703 & $209.491 .450,40$ & 37,52 \\
2010 & 89.952 .795 & $286.096 .194,80$ & 31,44 \\
2011 & 99.644 .869 & $278.156 .782,70$ & 35,82 \\
2012 & 105.984 .394 & $314.809 .204,40$ & 33,66 \\
2013 & 112.132 .672 & $155.842 .448,30$ & 71,95 \\
\hline
\end{tabular}

Sumber: Analisis Data Sekunder, 2014.

Berdasarkan tabel 7 sesuai standar perhitungan rasio cadangan risiko terhadap pinjaman bermasalah KSP pada tahun 2009, 2010, 2011 dan 2012 terletak pada rasio $30 \%<\mathrm{X} \leq 40 \%$ dengan skor 2,0 artinya bahwa cadangan risiko yang dimiliki KSP masih kurang mampu untuk menutupi apabila ada risiko pinjaman bermasalah. Terlihat dari skor yang didapatkan masih jauh dari skor maksimal. Pada tahun 2013 mengalami peningkatan yang tinggi dengan 
rasio yang diperoleh yaitu $71,95 \%$ yang terletak pada rasio $70 \%<X \leq 80 \%$ dengan skor 4,00 dengan skala 0 sampai dengan 5 artinya bahwa KSP pada tahun terakhir mengalami peningkatan setiap tahunya dalam menyediakan dana untuk pinjaman bermasalah dan sudah dianggap baik pada tahun terakhir.

Tabel 8. Rasio Pinjaman yang Berisiko terhadap Pinjaman yang Diberikan KSP Tani Makmur Tahun 2009-2013.

\begin{tabular}{cccc}
\hline Tahun & $\begin{array}{c}\text { Pinjaman yang } \\
\text { Berisiko } \\
(\mathrm{Rp})\end{array}$ & $\begin{array}{c}\text { Volume } \\
\text { Pinjaman yang } \\
\text { Diberikan (Rp) }\end{array}$ & $\begin{array}{c}\text { Rasio } \\
(\%)\end{array}$ \\
2009 & $72.424 .187,12$ & 1.197 .094 .002 & 6,05 \\
2010 & $105.687 .300,20$ & 1.682 .918 .793 & 6,28 \\
2011 & $106.205 .317,03$ & 1.685 .798 .683 & 6,30 \\
2012 & $119.627 .497,64$ & 1.798 .909 .739 & 6,65 \\
2013 & $122.657 .173,99$ & 1.833 .440 .568 & 6,69 \\
\hline
\end{tabular}

Sumber: Analisis Data Sekunder, 2014.

Berdasarkan tabel 8 sesuai standar perhitungan rasio pinjaman bermasalah yang berisiko yang diberikan kepada lain anggota pada tahun 20092013 memiliki rasio yang terletak di $<21 \%$ dengan skor 5,00 dengan skala 1,25 sampai 5 artinya bahwa risiko pinjaman bermasalah pada KSP memiliki nilai yang rendah dan pinjaman yang diberikan kepada lain anggota sedikit sehingga risiko yang didapatkan sedikit pula.

\section{Aspek Manajemen}

\section{Manajemen Umum}

Manajemen umum merupakan suatu gambaran terhadap KSP Tani Makmur mengenai perencaanaan yang telah dilakukan dan organisasi yang telah berjalan selama tahun 2009-2013. Hasil yang diperoleh atas jawaban pertanyaan dari aspek manajemen umum menggambarkan bahwa manajemen umum yang terdapat didalam KSP Tani Makmur sebagai berikut:

1. KSP Tani Makmur memiliki visi, misi dan tujuan yang jelas.

2. KSP Tani Makmur tidak memiliki rencana kerja jangka panjang

3. KSP Tani Makmur Memiliki rencana kerja tahunan yang digunakan sebagai dasar acuan kegiatan usaha selama 1 tahun.

4. KSP Tani Makmur hanya memiliki rencana kerja tahunan jangka pendek sehingga tidak ada penyesuaian dengan kerja tahunan jangka panjang.
5. Visi, misi, tujuan dan rencana kerja yang diketahui dan dipahami oleh pengurus, karyawan dan pengelola.

6. Pengambilankeputusan dilakukan oleh pengelola KSP Tani Makmur secara independent.

7. Pengurus KSPTani Makmur memiliki komitmen untuk menangani permasalahan yang dihadapi serta melakukan tindakan perbaikan.

8. KSP Tani Makmur memiliki tata terib kerja SDM yang meliputi disiplin kerja serta didukung sarana kerja yang memadai dalam melaksanakan pekerjaaan.

9. Pengurus KSP Tani Makmur yang mengangkat pengelola, tidak mencampuri kegiatan operasional.

10. Anggota KSP sebagai pemilik mempunyai kemampuan untuk meningkatkan permodalan KSP sesuai dengan ketentuan yang berlaku.

11. Pengurus, Pengawas dan Pengelola KSP Tani Makmur didalam melakukan kegiatan operasional yang dilakukan tidak melakukan hal-hal yang cenderung menguntungkan diri sendiri.

12. Pengurus KSP Tani Makmur melaksanakan fungsi pengawasan terhadap pelaksanaan tugas pengelola sesuai dengan tugas dan wewenangnya secara efektif.

Manajemen umum yang dimiliki KSP Tani Makmur memiliki jawaban "ya" sebanyak 10 dari 12 pertanyaan yang diajukan artinya bahwa manajemen umum KSP Tani Makmur sudah baik. Sesuai dengan standar perhitungan, manajemen umum yang dimiliki KSP pada tahun 2009-2013 memiliki skor 2,50 dari skor 0,25 sampai 3,00 dapat diartikan bahwa manajemen umum yang dilakukan selama ini tergolong baik.

\section{$\underline{\text { Kelembagaan }}$}

Kelembagaan merupakan aspek yang menggambarkan keadaan struktur bagan yang terdapat di dalam KSP Tani Makmur untuk menjalankan aktivitas dalam organisasi yang telah berjalan selama periode 2009-2013. Hasil yang diperoleh atas jawaban pertanyaan dari manajemen kelembagan menggambarkan bahwa KSP Tani Makmur:

1. Bagan organisasi yang ada selama tahun 20092013 telah mencerminkan seluruh kegiatan KSP dan tidak terdapat jabatan kosong atau perangkapan jabatan. 
2. KSP Memiliki rincian tugas yang jelas untuk masing-masing karyawannya.

3. Di dalam struktur kelembagaan KSP terdapat struktur yang melakukan fungsi sebagai dewan pengawas.

4. KSP tidak mempunyai Standar Operasional dan Manajemen (SOM) dan Standar Operasional Prosedur (SOP) dan tidakMenjalankan kegiatan sesuai SOM dan SOP.

5. Memiliki sistem pengamanan yang baik terhadap semua dokumen penting. Pengamanan yang dilakukan terhadap dokumen penting dilakukan dengan aman dan terjaga serta terdapat dokumen yang terdapat dalam komputer dengan program komputer yang baik.

Kelembagaan yang dimiliki KSP Tani Makmur memiliki jawaban "ya" sebanyak 4 dari 6 pertanyaan yang diajukan artinya bahwa kelembagaan KSP Tani Makmur cukup baik. Sesuai dengan standar perhitungan, manajemen umum yang dimiliki KSP pada tahun 2009-2013 memiliki skor 2,0 dari skor 0,50 sampai 3,00 hal ini tergolong cukup baik karna skor yang didapatkan mendekati nilai maksimal.

\section{Manajemen Permodalan}

Manajemen permodalan merupakan suatu perencanaan yang disusun KSP Tani Makmur dalam mengelola permodalan yang ada dalam usahanya selama tahun 2009-2013. Pertanyaan yang diajukan untuk melihat kinerja yang dilihat dari aspek manajemen permodalan untuk KSP Tani Makmur berdasarkan Peraturan Menteri Negara Koperasi dan Usaha Kecil dan Menengah No. 14/ Per/M.KUKM/XII/2009. Berikut ini manajemen permodalan yang dilakukan KSP Tani Makmur selama periode 2009-2013:

1. Pertumbuhan modal sendiri pada tahun 2011 mengalami tingkat pertumbuhan yang lebih besar dari pada tingkat pertumbuhan asset. Pada tahun 2009, 2010, 2012 dan 2013 tidak mengalami tingkat pertumbuhan modal sendiri yang lebih besar dari pada tingkat pertumbuhan aset.

2. Tingkat pertumbuhan modal sendiri yang berasal dari anggota yang memiiki tingkat pertumbuhan yang lebih dari $10 \%$ yaitu pada tahun 2009 dan tahun 2011. Pada tahun 2010, 2012 dan 2013 tingkat pertumbuhan modal sendiri yang berasal dari anggota kurang dari $10 \%$.
3. Penyisihan cadangan dari SHU yang dimiliki KSP pada tahun 2009-2013 mempunyai nilai yang lebih besar dari seperempat SHU Tahun Berjalan.

4. Simpanan dan simpanan berjangka KSP Tani Makmur pada tahun 2009, 2010, 2011 dan 2013 meningkat lebih dari $10 \%$. Pada tahun 2012 mengalami penurunan dari tahun sebelumnya.

5. Investasi harta tetap dari inventaris serta pendanaan ekspansi perkantoran KSP tidak dibiayai dengan modal sendiri.

Manajemen permodalan yang dimiliki KSP pada tahun 2011 memiliki jawaban "ya" sebanyak 4 dari 5 pertanyaan yang diajukan artinya bahwa pada tahun 2011 manajemen permodalan tergolong baik dengan skor 2,40 dari skala 0,60 sampai 5. Pada tahun 2009 memiliki jawaban "ya" sebanyak 3 dengan skor 1,80. Pada tahun 2010, 2012 dan 2013 memiliki jawaban "ya" sebanyak 2 dengan skor 1,20 artinya bahwa pada tahun-tahun tersebut manajemen permodalan tergolong kurang baik.

\section{Manajemen Aktiva}

Manajemen aktiva merupakan suatu gambaran perencanaan yang telah dilakukan KSP Tani Makmur mengenai aspek pengelolaan aktiva dengan total aset yang telah dilakukan selama tahun 2009-2013. Hasil yang diperoleh atas jawaban pertanyaan dari manajemen aktiva menggambarkan bahwa KSP Tani Makmur:

1. Pinjaman dengan kolektibiitas lancar dari pinjaman yang diberikan KSP pada tahun 2009-2013 memiliki nilai rasio lebih kecil dari $90 \%$.

2. Kebijakan yang ditetapkan oleh KSP pada tahun 2009-2013 mengenai pinjaman yang diberikan harus didukung dengan agunan berupa BPKB minimal tahun 2000 atau dalam bentuk sertifikat tanah.

3. Dana cadangan yang dimiliki KSP Tani Makmur tahun 2009-2013 lebih besar dari pada pinjaman macet

4. Pinjaman macet KSP pada tahun $2009-2013$ mengalami peningkatan sehingga belum ada penagihan yang dilakukan selama ini.

5. KSP Tani Makmur menerapkan prosedur pinjaman yang dilaksanakan dengan efektif. 
6. Pengambilan keputusan pemberian pinjaman yang dilakukan KSP Tani Makmur pada tahun 2009-2013 berdasarkan prinsip kehati-hatian yang diterapkan melalui kaidah 5C.

7. Keputusan pemberian pinjaman yang diterapkan KSP Tani Makmur pada tahun 2009-2013 selalu dilakukan melalui rapat komite

8. Pemantauan dilakukan oleh petugas lapangan dan terdapat laporan monitoring untuk setiap kali pengecekan yang dilakukan.

9. KSP selalu melakukan peninjauan, penilaian dan pengikatan terhadap agunan yang diberikan dari peminjam untuk memastikan agunan yang diberikan benar adanya

Manajemen aktiva yang dimiliki KSP pada tahun 2009-2013 memiliki jawaban "ya" sebanyak 8 dari 10 pertanyaan yang diajukan artinya bahwa kebijakan dalam mengatur aktiva yang dimiliki cukup baik. Sesuai dengan standar perhitungan, manajemen umum yang dimiliki KSP pada tahun 2009-2013 memiliki skor 2,40 dari skor 0,30 sampai 3,00 hal ini tergolong cukup baik karna skor yang didapatkan mendekati nilai maksimal.

\section{Manajemen Likuiditas}

Manajemen likuiditas merupakan kemampuan KSP Tani Makmur dalam menjaga likuiditas yang dmilikinya. Hasil yang diperoleh atas jawaban pertanyaan dari manajemen likuiditas menggambarkan bahwa KSP Tani Makmur:

1. KSP memiliki kebijaksanaan tertulis mengenai pengendalian likuiditas dengan menghitung bunga bank dan persediaan kas yang direncanakan untuk operasional atau keperluan hutang lancar. Kebijaksanaan tertulis terdapat dalam RAPB selama tahun 2009-2013.

2. KSP memiliki fasilitas pinjaman yang diterima dari lembaga lain untuk menjaga likuiditasnya.

3. KSP memiliki pedoman administratif yang efektif untuk memantau kewajiban yang jatuh tempo.

4. KSP memiliki kebijakan penghimpunan simpanan dan pemberian pinjaman sesuai dengan kondisi keuangan yang ada di KSP.

5. KSP memiliki sistem informasi manajemen yang memadai untuk pemantauan likuiditas.

Manajemen likuiditas yang dimiliki KSP pada tahun 2009-2013 memiliki jawaban "ya" sebanyak
5 dari 5 pertanyaan yang diajukan artinya bahwa kebijakan dalam mengatur likuiditas yang dimiliki tergolong baik. Sesuai dengan standar perhitungan, manajemen umum yang dimiliki KSP pada tahun 2009-2013 memiliki skor 3,0 dari skala 0,60 sampai 3,00 hal ini tergolong baik karna skor yang didapatkan mempunyai nilai maksimal.

\section{Aspek Efisiensi}

Aspek efisiensi dalam KSP Tani Makmur merupakan aspek yang menggambarkan kemampuan KSP Tani Makmur dalam memberikan pelayanan yang efisien kepada anggotanya dari penggunaan aset yang dimilikinya.

Tabel 9. Rasio Biaya Operasional Pelayanan terhadap Partisipasi Bruto KSP Tani Makmur Tahun 2009-2013.

\begin{tabular}{clcc}
\hline Tahun & $\begin{array}{c}\text { Beban } \\
\text { Operasional (Rp) }\end{array}$ & $\begin{array}{c}\text { Partisipasi } \\
\text { Bruto (Rp) }\end{array}$ & $\begin{array}{c}\text { Rasio } \\
(\%)\end{array}$ \\
2009 & 260.656 .370 & 664.524 .375 & 39,22 \\
2010 & 306.297 .445 & 954.118 .675 & 32,10 \\
2011 & 309.217 .964 & 963.847 .364 & 32,08 \\
2012 & 310.762 .336 & 1.430 .352 .614 & 21,72 \\
2013 & 340.762 .336 & 1.938 .476 .122 & 17,58 \\
\hline
\end{tabular}

Sumber: Analisis Data Sekunder, 2014.

Berdasarkan tabel 9 sesuai standar perhitungan rasio beban operasi terhadap partisipasi bruto KSP pada tahun 2009-2013 terletak pada rasio $0 \% \leq \mathrm{X}$ $<90 \%$ dengan skor yang dimiliki 4 untuk skala 1 sampai dengan 4 artinya bahwa KSP Tani Makmur mempunyai nilai tertinggi dan dinilai sangat baik karena beban operasi anggota dapat ditutup dengan partisipasi bruto yang diperoleh dari anggota.

Tabel 10. Rasio Beban Usaha terhadap SHU Kotor KSP Tani Makmur Tahun 2009-2013.

\begin{tabular}{c|l|c|c}
\hline Tahun & \multicolumn{1}{c}{$\begin{array}{c}\text { Beban Usaha } \\
(\mathrm{Rp})\end{array}$} & $\begin{array}{c}\text { SHU Kotor } \\
(\mathrm{Rp})\end{array}$ & Rasio (\%) \\
2009 & 16.483 .790 & 31.102 .924 & 52,99 \\
2010 & 7.487 .593 & 21.741 .086 & 34,44 \\
2011 & 61.496 .851 & 79.767 .106 & 77,09 \\
2012 & 23.631 .235 & 40.432 .100 & 58,45 \\
2013 & 6.812 .471 & 33.847 .038 & 20,12 \\
\hline
\end{tabular}

Sumber: Analisis Data Sekunder, 2014.

Berdasarkan tabel 10 sesuai dengan standar perhitungan KSP Tani Makmur mengenai rasio beban usaha terhadap SHU Kotor pada tahun 2010 dan 2013 yang diperoleh yaitu 34,44\% dan 
20,12\%. Pada tahun 2010 dan 2013 terletak dirasio $0 \%<\mathrm{X} \leq 40 \%$ dengan skor 4 pada skala 1 sampai 4 . Skor maksimal yang didapatkan pada tahun 2010 dan 2013 menggambarkan KSP mampu mengefisienkan modalnya dengan mengeluarkan biaya sekecilkecilnya untuk mempunyai keuntungan (SHU).

Pada Tahun 2009 dan 2012 KSP Tani Makmur mengalami penurunan dalam pengelolaan modal dengan baik, rasio yang diperoleh pada tahun 2009 dan 2012 yaitu $52,99 \%$ dan $58,45 \%$ yang terletak di rasio $40 \%<\mathrm{X} \leq 60 \%$ dengan skor 3 . Pada Tahun 2011 merupakan rasio yang paling besar yang diperoleh yaitu sebesar $77,09 \%$ yang terletak di rasio $60 \%<\mathrm{X} \leq 80 \%$ dengan skor 2 artinya bahwa KSP belum dapat menefisiensikan modalnya dengan baik untuk memperoleh SHU.

Tabel 11. Rasio Efisiensi Pelayanan KSP Tani Makmur Tahun 2009-2013.

\begin{tabular}{cccc}
\hline Tahun & $\begin{array}{c}\text { Biaya Karyawan } \\
(\mathrm{Rp})\end{array}$ & $\begin{array}{c}\text { Volume } \\
\text { Pinjaman (Rp) }\end{array}$ & $\begin{array}{c}\text { Rasio } \\
(\%)\end{array}$ \\
2009 & 24.050 .000 & 1.197 .094 .002 & 2,10 \\
2010 & 27.917 .500 & 1.682 .918 .793 & 1,66 \\
2011 & 23.914 .000 & 1.685 .798 .683 & 1,42 \\
2012 & 22.996 .500 & 1.798 .909 .739 & 1,28 \\
2013 & 24.377 .000 & 1.833 .440 .568 & 1,33 \\
\hline
\end{tabular}

Sumber: Analisis Data Sekunder, 2014.

Berdasarkan tabel 11 sesuai standar perhitungan rasio efisiensi pelayanan yang diperoleh KSP pada tahun 2009-2013 terletak pada rasio $\leq 5 \%$ dan memiliki skor tertinggi 2,0 untuk skala 0 sampai dengan 2. KSP memiliki pelayanan yang sangat baik terlihat dari skor yang didapatkan.

\section{Aspek Likuiditas}

Aspek likuiditas dalam KSP Tani Makmur merupakan aspek yang menggambarkan kemampuan KSP Tani Makmur untuk memenuhi kewajiban finansialnya yang segera harus dipenuhi atau kewajiban jangka pendek.

Berdasarkan tabel 12 sesuai standar perhitungan rasio kas dan bank terhadap kewajiban lancar KSP pada tahun 2009-2013 terletak di rasio $>20 \%$ dengan skor 2,5 dnegan skala 2,5 sampai 5. KSP pada tahun 2009-2013 dinilai tidak mampu mengelola kas dan banknya dengan baik untuk memenuhi kewajiban jangka pendek terlihat dari skor yang diperoleh merupakan skor yang terendah.
Tabel 12. Rasio Kas dan Bank terhadap Kewajiban Lancar KSP Tani Makmur Tahun 2009-2013.

\begin{tabular}{cccc}
\hline Tahun & $\begin{array}{c}\text { Kas + Bank } \\
(\mathrm{Rp})\end{array}$ & $\begin{array}{c}\text { Hutang Lancar } \\
(\mathrm{Rp})\end{array}$ & Rasio (\%) \\
2009 & 357.083 .953 & 946.788 .964 & 37,71 \\
2010 & 383.306 .934 & 1.280 .398 .343 & 29,94 \\
2011 & 332.345 .599 & 1.329 .329 .387 & 25,00 \\
2012 & 698.231 .152 & 1.943 .021 .912 & 35,93 \\
2013 & 801.696 .804 & 2.325 .479 .263 & 34,47 \\
\hline
\end{tabular}

Sumber: Analisis Data Sekunder, 2014.

Tabel 13. Rasio Pinjaman yang Diberikan terhadap Dana yang Diterima KSP Tani Makmur Tahun 2009-2013

\begin{tabular}{cccc}
\hline Tahun & $\begin{array}{c}\text { Pinjaman yang } \\
\text { Diberikan (Rp) }\end{array}$ & $\begin{array}{c}\text { Dana yang } \\
\text { Diterima (Rp) }\end{array}$ & $\begin{array}{c}\text { Rasio } \\
(\%)\end{array}$ \\
2009 & 1.197 .094 .002 & 1.599 .816 .178 & 74,83 \\
2010 & 1.682 .918 .793 & 2.112 .758 .541 & 79,65 \\
2011 & 1.685 .798 .683 & 2.063 .496 .556 & 81,69 \\
2012 & 1.798 .909 .739 & 2.540 .733 .420 & 70,80 \\
2013 & 1.833 .440 .568 & 2.713 .682 .572 & 67,56 \\
\hline
\end{tabular}

Sumber: Analisis Data Sekunder, 2014.

Berdasarkan tabel 13 sesuai standar perhitungan rasio pinjaman yang diberikan terhadap dana yang diterima yang diperoleh KSP pada tahun 2009, 2010 dan 2012 terletak pada rasio $70 \% \leq \mathrm{X}<80 \%$ dengan skor 3,75 untuk skala 1,25 sampai dengan 5. Kemampuan KSP dalam menegelola dana yang dimiliki untuk pinjaman yang diberikan dianggap cukup baik.

Pada tahun 2011 terletak pada rasio $80 \%$ $\leq \mathrm{X}<90 \%$ dengan perolehan skor maksimal yaitu 5. Pada tahun 2011 KSP tergolong baik dalam mengelola dana yang dimiliki. Pada tahun 2013 terletak di rasio $60 \% \leq \mathrm{X}<70 \%$ dengan skor 2,50 artinya bahwa KSP kurang baik dalam mengoptimalkan dana yang dimiliki.

\section{Aspek Kemandirian dan Pertumbuhan}

Aspek kemandirian dan pertumbuhan merupakan aspek yang menggambarkan kemampuan KSP dalam memperoleh keuntungan yang diharapkan dan keberlangsungan KSP dalam menjalankan organisasinya

Berdasarkan tabel 14 sesuai standar perhitungan rasio rentabilitas aset KSP pada tahun 2009-2013 sesuai standar perhitunganterletak di rasio $\leq 5 \%$ dengan skor 0,75 untuk skala 0,75 sampai dengan 3,00. KSP tidak mampu memperoleh SHU yang diterima secara maksimal. 
Tabel 14. Rasio Rentabilitas Aset KSP Tani Makmur Tahun 2009-2013

\begin{tabular}{cccc}
\hline Tahun & $\begin{array}{c}\text { SHU sebelum } \\
\text { pajak (Rp) }\end{array}$ & Total Aset (Rp) & $\begin{array}{c}\text { Rasio } \\
(\%)\end{array}$ \\
2009 & 31.102 .924 & 1.644 .377 .871 & 1,89 \\
2010 & 21.741 .086 & 2.160 .424 .865 & 1,00 \\
2011 & 79.767 .106 & 2.115 .666 .157 & 3,77 \\
2012 & 40.432 .100 & 2.599 .807 .031 & 1,55 \\
2013 & 33.847 .038 & 2.776 .262 .063 & 1,22 \\
\hline
\end{tabular}

Sumber: Analisis Data Sekunder, 2014.

Tabel 15. Rasio Rentabilitas Moda Sendiri KSP Tani Makmur Tahun 2009-2013.

\begin{tabular}{cccc}
\hline Tahun & $\begin{array}{c}\text { SHU bagian } \\
\text { anggota (Rp) }\end{array}$ & $\begin{array}{c}\text { Total Modal } \\
\text { Sendiri (Rp) }\end{array}$ & $\begin{array}{c}\text { Rasio } \\
(\%)\end{array}$ \\
2009 & 31.420 .826 & 151.477 .204 & 20,74 \\
2010 & 37.922 .507 & 156.048 .106 & 24,30 \\
2011 & 42.001 .558 & 219.419 .611 & 19,14 \\
2012 & 54.231 .496 & 200.556 .449 & 27,04 \\
2013 & 60.840 .090 & 205.400 .114 & 29,62 \\
\hline
\end{tabular}

Sumber: Analisis Data Sekunder, 2014.

Berdasarkan tabel 15 sesuai standar perhitungan rasio rentabilitas modal sendiri KSP pada tahun 2009-2013 rasio rentabilitas modal sendiri yang dimiliki KSP terletak pada rasio $\geq 5 \%$ dengan skor 3,00 untuk skala 0,75 sampai dengan 3,00. KSP mempunyai kemampuan dalam menggunakan modal sendiri untuk menghasilkan SHU.

Tabel 16. Rasio Kemandirian Operasional Pelayanan KSP Tani Makmur Tahun 2009-2013

\begin{tabular}{cccc}
\hline Tahun & $\begin{array}{c}\text { Partisipasi } \\
\text { Neto (Rp) }\end{array}$ & $\begin{array}{c}\text { Beban Usaha } \\
\text { +Beban } \\
\text { Perkoperasian (Rp) }\end{array}$ & Rasio \\
& & \\
2009 & 621.290 .423 & 282.171 .710 & 220,18 \\
2010 & 900.482 .033 & 337.983 .077 & 266,43 \\
2011 & 903.684 .241 & 336.110 .460 & 268,86 \\
2012 & 1.430 .352 .614 & 335.172 .942 & 426,75 \\
2013 & 1.927 .902 .371 & 365.305 .537 & 527,75 \\
\hline
\end{tabular}

Sumber: Analisis Data Sekunder, 2014.

Berdasarkan tabel 16 sesuai standar perhitungan rasio kemandirian operasional KSP yang diperoleh pada tahun 2009-2013 mengenai rasio kemandirian operasional pelayanan terletak di rasio $>100 \%$ dengan skor tertinggi yaitu 4 . KSP sudah sangat baik selama tahun 2009-2013 untuk memenuhi biaya-biaya yang dikeluarkan dengan menggunakan pendapatan yang diterima.

\section{Aspek Jatidiri Koperasi}

Penilaian pada aspek jatidiri KSP Tani Makmur bertujuan untuk mengukur keberhasilan KSP Tani Makmur dalam mencapai tujuannya yaitu dengan mempromosikan ekonomi anggota. Kemampuan KSP dalam memberikan nilainilai pada koperasi sebagai usaha bersama bagi pengelola dan anggota akan memberikan dampak pada kebijakan-kebijakan yang diterapkan KSP.

Tabel 17. Rasio Partisipasi Bruto KSP Tani Makmur Tahun 2009-2013.

\begin{tabular}{cccc}
\hline Tahun & $\begin{array}{c}\text { Partisipasi } \\
\text { Bruto (Rp) }\end{array}$ & $\begin{array}{c}\text { Partisipasi Bruto } \\
\text { + Pendapatan } \\
(\mathrm{Rp})\end{array}$ & $\begin{array}{c}\text { Rasio } \\
(\%)\end{array}$ \\
2009 & 664.524 .375 & 961.834 .275 & 69,09 \\
2010 & 954.118 .675 & 1.294 .810 .715 & 73,69 \\
2011 & 963.847 .364 & 1.358 .016 .234 & 70,97 \\
2012 & 1.430 .352 .614 & 1.785 .377 .995 & 80,11 \\
2013 & 1.938 .476 .122 & 2.309 .432 .534 & 83,94 \\
\hline
\end{tabular}

Sumber: Analisis Data Sekunder, 2014.

Berdasarkan tabel 17 sesuai standar perhitungan rasio partisipasi bruto KSP pada tahun 2009, 2010 dan 2011 mempunyai rasio yang terletak pada rasio $50 \% \leq \mathrm{X}<75 \%$ dan memiliki skor 5,25 dengan skala rasio 1,75 sampai 7,00. Tingkat partisipasi yang dimilikinya cukup baik. Kenaikan angka rasio terjadi pada tahun 2012 dan 2013 terletak di rasio $\geq 75 \%$ dengan skor 7,00. Peningkatan terjadi pada partisipasi anggota dari tahun-tahun sebelumnya dalam mempunyai pendapatan.

Tabel 18. Rasio Promosi Ekonomi Anggota KSP Tani Makmur Tahun 2009-2013.

\begin{tabular}{cccc}
\hline Tahun & $\begin{array}{c}\text { Promosi } \\
\text { Ekonomi } \\
\text { Anggota (Rp) }\end{array}$ & $\begin{array}{c}\text { Simpanan Pokok } \\
\text { + Simpanan } \\
\text { Wajib (Rp) }\end{array}$ & $\begin{array}{c}\text { Rasio } \\
(\%)\end{array}$ \\
2009 & 6.722 .276 & 8.950 .000 & 75,11 \\
2010 & 4.519 .093 & 11.965 .000 & 37,77 \\
2011 & 9.020 .254 & 13.655 .000 & 66,06 \\
2012 & 7.039 .666 & 16.115 .000 & 43,68 \\
2013 & 11.568 .134 & 18.050 .000 & 64,09 \\
\hline
\end{tabular}

Sumber: Analisis Data Sekunder, 2014.

Berdasarkan tabel 18 sesuai standar perhitungan rasio promosi ekonomi anggota KSP pada tahun 2009-2013 terletak pada rasio $>10 \%$ dengan skor 3,00 dengan skala 0 sampai dengan 3. KSP Tani Makmur sudah memaksimalkan 
kinerja simpanan pokok dan simpanan wajib yang disetorkan anggota KSP untuk mempunyai keuntungan yang diinginkan KSP.

\section{Kinerja KSP Tani Makmur Tahun 2009-2013 Secara Keseluruhan}

Kinerja KSP Tani Makmur secara keseluruhan dapat dinilai dengan menjumlahkan skor yang diperoleh dari berbagai aspek. Penilaian Kinerja dilakukan pada tahun 2009-2013. Penilaian aspek secara keseluruhan pada KSP dilihat dari aspek permodalan, kualitas aktiva produktif, manajemen, efisiensi, likuiditas, pertumbuhan dan perkembangan serta jatidiri koperasi.
Aspek jati diri koperasi merupakan aspek yang paling utama dibanding dengan aspek-aspek lainnya. Aspek jatidiri menggambarkan upaya KSP dalam memberikan nilai-nilai yang tertanam pada koperasi bagi pengelola dan anggota. Nilai-nilai pada koperasi berdampak pada kebijakan yang akan diambil sebagai organisasi yang dikelola secara bersama. Hasil penilaian kinerja KSP Tani Makmur secara keseluruhan dapat dilihat pada Tabel 19.

Penilaian kinerja KSP Tani Makmur 20092013 dilihat dari beberapa aspek yaitu aspek permodalan, aspek kualitas aktiva produktif, aspek manajemen, aspek efisiensi, aspek likuiditas, aspek kemandirian dan pertumbuhan dan aspek jatidiri

Tabel 19 Hasil Penilaian Kinerja KSP Tani Makmur Tahun 2009-2013.

\begin{tabular}{|c|c|c|c|c|c|}
\hline \multirow{2}{*}{ ASPEK } & \multicolumn{5}{|c|}{ SKOR (Tahun) } \\
\hline & 2009 & 2010 & 2011 & 2012 & 2013 \\
\hline \multicolumn{6}{|l|}{ PERMODALAN } \\
\hline a. Rasio modal sendiri terhadap total asset & 1,50 & 1,50 & 1,50 & 1,50 & 1,50 \\
\hline $\begin{array}{l}\text { b. Rasio modal sendiri terhadap pinjaman diberikan } \\
\text { berisiko }\end{array}$ & 0,60 & 0,00 & 0,60 & 0,60 & 0,60 \\
\hline c. Rasio kecukupan modal sendiri & 3,00 & 2,25 & 3,00 & 3,00 & 3,00 \\
\hline \multicolumn{6}{|l|}{ KUALITAS AKTIVA PRODUKTIF } \\
\hline $\begin{array}{l}\text { a. Rasio volume pinjaman pada anggota terhadap volume } \\
\text { pinjaman diberikan }\end{array}$ & 10,00 & 10,00 & 10,00 & 10,00 & 10,00 \\
\hline $\begin{array}{l}\text { b. Rasio risiko pinjaman bermasalah terhadap pinjaman } \\
\text { yang diberikan }\end{array}$ & 3,00 & 3,00 & 3,00 & 3,00 & 4,00 \\
\hline c. Rasio cadangan risiko terhadap pinjaman bermasalah & 2,00 & 2,00 & 2,00 & 2,00 & 4,00 \\
\hline $\begin{array}{l}\text { d. Rasio pinjaman yang berisiko terhadap pinjaman yang } \\
\text { diberikan }\end{array}$ & 5,00 & 5,00 & 5,00 & 5,00 & 5,00 \\
\hline \multicolumn{6}{|l|}{ MANAJEMEN } \\
\hline a. Manajemen Umum & 2,50 & 2,50 & 2,50 & 2,50 & 2,50 \\
\hline b. Kelembagaan & 2,00 & 2,00 & 2,00 & 2,00 & 2,00 \\
\hline c. Manajemen Permodalan & 1,80 & 1,20 & 2,40 & 0,60 & 1,20 \\
\hline d. Manajemen Aktiva & 2,40 & 2,40 & 2,40 & 2,40 & 2,40 \\
\hline e. Manajemen Likuiditas & 3,00 & 3,00 & 3,00 & 3,00 & 3,00 \\
\hline \multicolumn{6}{|l|}{ EFISIENSI } \\
\hline a. Rasio beban operasi anggota terhadap partisipasi bruto & 4,00 & 4,00 & 4,00 & 4,00 & 4,00 \\
\hline b. Rasio beban usaha terhadap SHU kotor & 3,00 & 4,00 & 2,00 & 3,00 & 4,00 \\
\hline c. Rasio efisiensi pelayanan & 2,00 & 2,00 & 2,00 & 2,00 & 2,00 \\
\hline \multicolumn{6}{|l|}{ LIKUIDITAS } \\
\hline a. Rasio kas & 2,50 & 2,50 & 2,50 & 2,50 & 2,50 \\
\hline $\begin{array}{l}\text { b. Rasio pinjaman yang diberikan terhadap dana yang } \\
\text { diterima }\end{array}$ & 3,75 & 3,75 & 5,00 & 3,75 & 2,50 \\
\hline \multicolumn{6}{|l|}{ KEMANDIRIAN DAN PERTUMBUHAN } \\
\hline a. Rentabilitas aset & 0,75 & 0,75 & 0,75 & 0,75 & 0,75 \\
\hline b. Rentabilitas modal sendiri & 3,00 & 3,00 & 3,00 & 3,00 & 3,00 \\
\hline c. Kemandirian operasional pelayanan & 4,00 & 4,00 & 4,00 & 4,00 & 4,00 \\
\hline \multicolumn{6}{|l|}{ JATIDIRI KOPERASI } \\
\hline a. Rasio partisipasi bruto & 5,25 & 5,25 & 5,25 & 7,00 & 7,00 \\
\hline b. Rasio promosi ekonomi anggota & 3,00 & 3,00 & 3,00 & 3,00 & 3,00 \\
\hline Jumlah & 67,80 & 67,10 & 68,90 & 68,60 & 71,95 \\
\hline
\end{tabular}

Sumber: Analisis Data Sekunder, 2014. 
koperasi. Secara keseluruhan tahun 2009-2013 KSP Tani Makmur memiliki angka rasio yang terletak di rasio $60 \% \leq \mathrm{X}<80 \%$ dengan predikat cukup sehat yang sesuai dengan standar perhitungan Peraturan Menteri Negara Koperasi dan Usaha Kecil dan Menengah tahun 2009.

\section{KESIMPULAN}

1. Aspek permodalan kinerja KSP Tani Makmur tahun 2010 mempunyai skor 3,75. Tahun 2009, 2011, 2012 dan 2013 mempunyai skor 5,10 dari keseluruhan skor 15 . Hal ini menggambarkan bahwa permodalan KSP belum dapat mandiri dan mempunyai ketergantungan terhadap pihak eksternal.

2. Aspek kualitas aktiva produktif kinerja KSP Tani Makmur tahun 2009, 2010, 2011 dan 2012 mempunyai skor 20. Tahun 2013 mempunyai skor 23 dari keseluruhan skor 25 . Hal ini menggambarkan kemampuan KSP Tani Makmur dalam memberikan pinjaman dan kualitas pelayanan kepada anggota semakin meningkat pada tahun terakhir.

3. Aspek manajemen kinerja KSP Tani Makmur tahun 2009 mempunyai skor 10,45. Tahun 2012 mempunyai skor 9,50. Pada tahun 2010 dan 2013 mempunyai skor 11,10. Pada tahun 2011 mempunyai skor 11,90 dari keseluruhan skor 15. Hal ini menggambarkan kemampuan manajemen KSPTani Makmur dalam mengelola usahanya dinilai baik.

4. Aspek efisiensi kinerja KSP Tani Makmur tahun 2011 mempunyai skor 8. Pada tahun 2009 dan 2012 mempunyai skor 9. Tahun 2010 dan 2013 mempunyai skor yaitu 10 dari total keseluruhan 10. Hal ini menggambarkan pelayanan yang efisien kepada anggotanya dari penggunaan aset yang dimilikinya secara keseluruhan dinilai baik.

5. Aspek likuiditas kinerja KSP Tani Makmur tahun 2009, 2010 dan 2012 mempunyai skor 6,25. Pada tahun 2011 mempunyai skor 7,50. Pada tahun 2013 mempunyai skor 5,00 dari keseluruhan skor 15. Hal ini menggambarkan kemampuan KSP Tani Makmur pada tahuntahun berikutnya dalam memenuhi kewajiban finansialnya yang segera harus dipenuhi atau kewajiban jangka pendek dinilai tidak baik.

6. Aspek kemandirian dan pertumbuhan kinerja KSP Tani Makmur tahun 2009-2013 mempunyai skor 7,75 dari keseluruhan skor 10. Hal ini menggambarkan kemampuan KSP Tani Makmur pada tahun 2009-2013 dalam memperoleh keuntungan yang diharapkan dan keberlangsungan menjalankan organisasinya dinilai cukup baik.

7. Aspek jatidiri koperasi kinerja KSP Tani Makmur tahun 2009, 2010 dan 2011 mempunyai yaitu 8,25. Tahun 2012 dan 2013 mempunyai skor 10 dari keseluruhan skor 10 . Hal ini menggambarkan keberhasilan KSP Tani Makmur dalam mencapai tujuannya yaitu dengan mempromosikan ekonomi anggota dinilai sangat baik.

8. Penilaian secara keseluruhan kinerja KSP Tani Makmur pada tahun 2009-2013 dinilai cukup sehat dengan skor pada tahun 2009 sebesar 67,80 . Tahun 2010 mempunyai skor 67,10 . Tahun 2011 mempunyai skor 68,90. Tahun 2012 mempunyai skor 68,60 . Tahun 2013 mempunyai skor 71,95 dari keseluruhan skor 100. Secara keseluruhan mendapatkan predikat cukup sehat dan skor yang didapatkan meningkat.

\section{SARAN}

1. Untuk meningkatkan kinerja keuangan dari aspek permodalan dapat diperbaiki dengan cara modal sendiri yang dimiliki harus lebih ditingkatkan. Terlihat dari besaran simpanan pokok sebesar Rp500,00 dan simpanan wajib sebesar Rp 100,00 selama tahun 2009-2013 masih tergolong rendah dalam pemenuhan kebutuhan operasional KSP Tani Makmur. Kemampuan dalam mengoptimalkan modal sendiri dapat melalui partisipasi anggota serta peningkatkan efisiensi kegiatan usaha simpan dan pinjam.

2. Perbaikan pada aspek manajemen dengan menerapkan SOM dan SOP, serta diperlukan pengendalian dan penagihan secara intensif pada pinjaman yang bermasalah sehingga mampu meningkatkan kolektibilitas lancar hingga $90 \%$.

3. Perbaikan pada aspek likuiditas dengan membatasi nilai kas dan bank yang dimiliki dengan rasio $10 \%$ hingga $15 \%$ terhadap kewajiban lancar. Kas dan bank dapat dialokisakan pada simpanan jangka pendek atau ke piutang anggota agar mudah dicairkan untuk pemenuhan kebutuhan yang mendadak. 
Pembenahan pada promosi ekonomi anggota dengan memberikan insentif bunga pinjaman yang lebih kecil sehingga anggota diharapkan dapat lebih berpartisipasi memanfaatkan program simpanan dan pinjaman.

4. Perbaikan pada aspek efisiensi dengan mengendalikan beban usaha pada THR karyawan dan kelompok sehingga kemampuan KSP dalam meningkatkan pendapatan dapat lebih baik.

5. Perbaikan pada aspek kemandirian dan pertumbuhan dengan meningkatkan SHU sehingga aset yang dimiliki mampu dibiayai dari kepemilikan sendiri bukan berasal dari pihak luar (utang).

6. Perbaikan pada aspek jati diri koperasi untuk partisipasi bruto dengan menerapkan nilai kepimilikan bersama. Meningkatkan pemahaman dan pengetahuan mengenai prinsip dan nilai-nilai koperasi yang sesuai dengan Undang-Undang Perkoperasian kepada pengelola dan anggota koperasi.

7. KSPTani Makmur diharapkan dapat membenahi aspek keuangan dan non keuangan yang dilakukan selama ini sesuai standar Peraturan Menteri Negara Koperasi dan Usaha Kecil dan Menengah Republik Indonesia Indonesia Nomor 14/Per/M.KUKM/XII/2009. Pembenahan dilakukan, misalnya dengan meninjau program piutang anggota agar dapat menghasilkan keuntungan lebih banyak sehingga diharapkan kriteria kesehatan KSP Tani Makmur dapat lebih baik.

\section{DAFTAR PUSTAKA}

Hendar. 2010. Manajemen Perusahaan Koperasi. Erlangga. Jakarta

Kaplan, R dan D.Norton. 1996. The Balanced Scorecard: Translating Startegy into Action. United State of America. Harvard Business School Press.

Sinaga, M. 2000. Teori Akuntansi. Edisi 4. Erlangga. Jakarta.

Suryabrata, S. 2011. Metodologi Penelitian. Cetakan ke-22. Rajawali Press. Jakarta.

Widiyati, N. 2010. Manajemen Koperasi. Rineka Cipta. Jakarta. 